\title{
HISTOCHEMICAL LOCALIZATION OF ACID UTERINE AMINOACYLNAPHTHYLAMIDASES IN EARLY PREGNANCY AND IN DIFFERENT HORMONAL STATES OF THE MOUSE
}

\author{
S. BERGSTRÖM \\ Department of Human Anatomy, University of Uppsala, S 75220 Uppsala, Sweden
}

(Received 9th Fune 1971, accepted 16th September 1971)

\begin{abstract}
Summary. Two different aminoacylnaphthylamidase reactions in the mouse uterus are described, a particulate one in the glandular epithelium and a vacuolar one in the luminal epithelium and at the implantation sites. Maximum epithelial enzyme activity was observed on Day 5 of pregnancy or after 6 days' progesterone treatment of the spayed mouse. No further increase was achieved after oestradiol superimposed on progesterone treatment. At implantation sites on Day 8, the activity was mainly localized antimesometrially to the embryo. It is suggested that the uterine epithelial activity contributes to the breakdown of uterine secretion before the attachment reaction.
\end{abstract}

\section{INTRODUGTION}

In pregnant mice, a faint proteolysis occurs at the implantation sites and a slightly stronger one in the adjacent luminal epithelium (Bergström, 1970). These results suggest that the uterine luminal epithelium may have an autolytic capacity during early pregnancy in the mouse. To test this hypothesis, a modification of a histochemical technique designed for acid naphthylamidases was used in the present study. This technique is claimed to demonstrate early cell injury, e.g. in autolysis (Niemi \& Sylvén, 1969).

\section{MATERIALS AND METHODS}

Virgin albino mice (NMRI, Bethesda) weighing about $20 \mathrm{~g}$ were used throughout this study. They were divided in two main groups: mice in the first group were mated and used during various stages of early pregnancy; mice in the second group were spayed 3 weeks before use.

The first group of mice was allowed to proceed to Day 2, 4, 5, 6 or 8 of pregnancy, Day 1 being the day on which a vaginal plug was found. The mice were killed by cervical dislocation at 09.00 hours on each of these days.

Mice in the second group were treated with combinations of progesterone and oestrogen according to Table 1 and subsequently killed in the same way as those in the first group.

At autopsy, the uteri were immediately removed in small pieces and freshly 
frozen in isopenthane cooled to $-79^{\circ} \mathrm{C}$ with dry-ice. Sections (10 $\mu \mathrm{m}$ thick) were then cut in a cryostat at about $-20^{\circ} \mathrm{C}$. For comparison, some other mice from both groups were given Nembutal intraperitoneally and perfused through the abdominal aorta with $2.5 \%$ glutaraldehyde buffered with phosphate buffer ( $\mathrm{pH} \mathrm{7.4)}$. Their uteri were removed after perfusion for $5 \mathrm{~min}$ and were subsequently embedded in polyethylene glycol (PEG) with a melting point of 37 to $38^{\circ} \mathrm{C}$ (Sandström \& Westman, 1969).

Sections of both freshly frozen and PEG-embedded uterine tissue were then processed along three lines.

(1) This procedure was designed to test the presence of cathepsin B (Sylvén, 1968) and was performed in seven steps (a to g) before mounting: (a) incubation in $0.05 \mathrm{M}$-acetate buffer at $\mathrm{pH} 5.5$ for $30 \mathrm{~min}$; (b) incubation in cysteine $(0.004 \mathrm{M})$ in $0.05 \mathrm{M}$-EDTA dissolved in the above buffer, $\mathrm{pH} 5.5$ at room temperature for $30 \mathrm{~min}$; (c) rinsing in fresh buffer as in (a) for several minutes; (d) incubation at $37^{\circ} \mathrm{C}$ in the substrate solution (Nachlas, Crawford \& Seligman, 1957) containing L-leucyl- $\beta$-naphthylamide (LNA) and tetrazotized diorthoanisidine (Diazo Blue B), for 30 to $40 \mathrm{~min}$ (cryostat sections) or for $3 \mathrm{hr}$ (PEG-embedded sections). The substrate, LNA, is split by a wide variety of enzymes irrespective of its L-leucyl component (Sylvén, 1968) and LNAsplitting enzymes are thus most correctly called aminoacylnaphthylamidases (AANA-ases). Substrate was dissolved in the $0.05 \mathrm{~m}$-acetate buffer; (e) rinsing in saline for $2 \mathrm{~min}$; (f) incubation in $0.1 \mathrm{M}$-cupric sulphate for $5 \mathrm{~min}$ to allow chelation of copper to the azo dye; (g) dehydration in graded concentrations of alcohol to xylol and then mounting in Caedax.

(2) This procedure was chosen to show whether or not acid cytoplasmic aminopeptidases were present in the sections (Sylvén, 1968) and was performed in almost the same way as was the 'cathepsin B' procedure above. The only deviation from this schedule concerned step (b), where preincubation was carried out in $0.01 \mathrm{M}-\mathrm{Mn}\left(\mathrm{NO}_{3}\right)_{2}$ dissolved in acetate buffer of $\mathrm{pH} 5.5$ as above instead of the cysteine-EDTA-incubation.

(3) This procedure served as a control with the exclusion of any of the previous preincubation baths. The purpose was to test the enzyme independence of $\mathrm{Mn}^{2+}$ and cysteine-EDTA.

\section{RESULTS}

The findings are summarized in Table 1.

Two different types of enzyme reaction were distinguished: a particulate one in the glandular epithelium (Pl. 1, Figs. 1 and 2) and a vacuolar one in the luminal epithelium (Pl. 1, Figs. 3 and 4). The latter type was also observed around the implantation sites (PI. 2, Figs. 5 and 6).

The structure was generally better preserved in fixed than in unfixed sections in spite of the six times longer incubation time required for the fixed sections.

Fixed tissues showed a lower activity than unfixed ones. The former had a yellowish background, absent from the latter, which was probably due to a denaturation effect on the proteins in the fixed tissue (Sylvén, personal communication). Localization of the enzyme activity in the fixed tissues was always 
PLATE 1
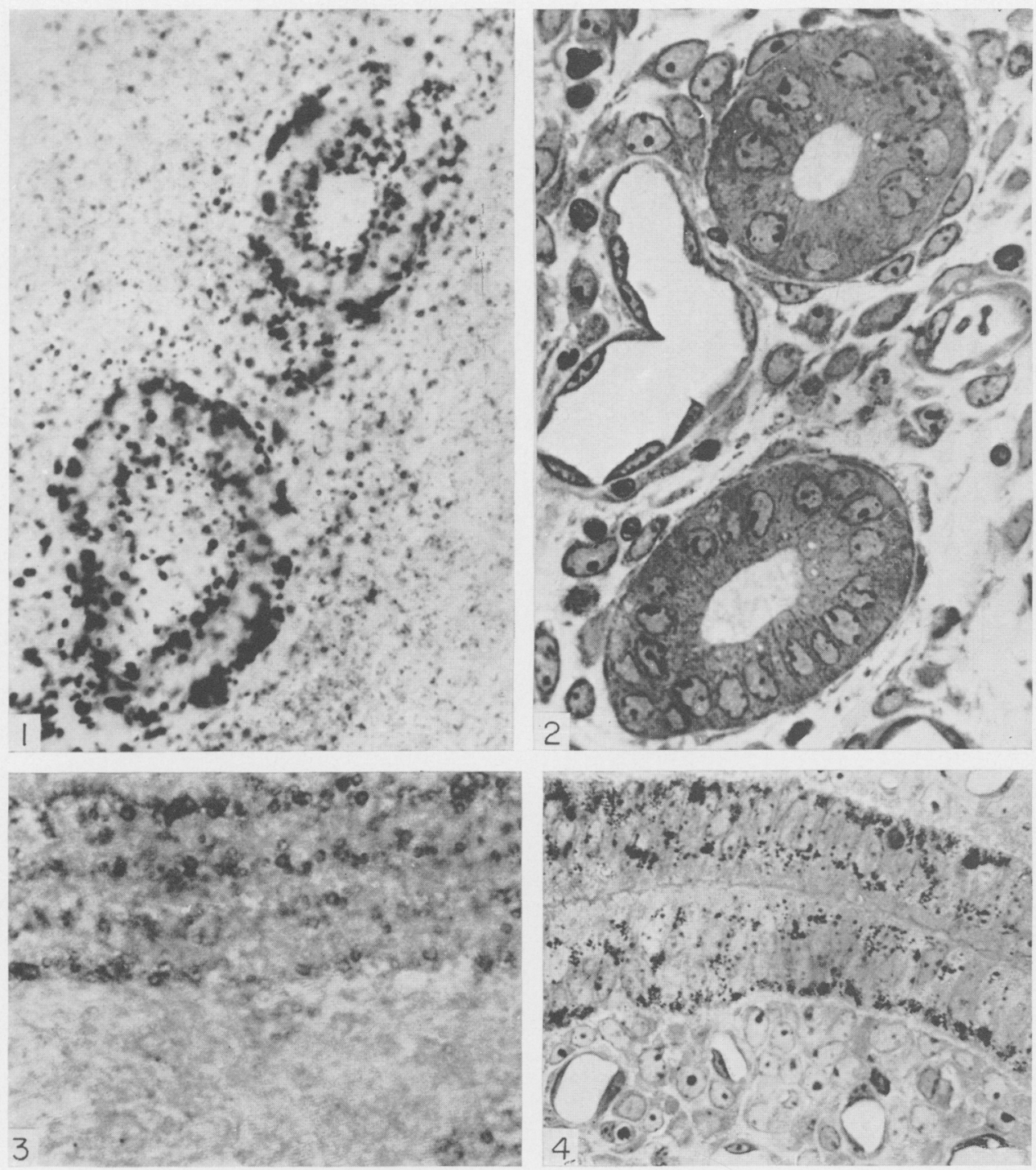

F'IG. 1. Mouse uterine glands on Day 5 of pregnancy. Cryostat section showing AANA-ase activity. $\times 550$.

Fig. 2. Mousc uterinc glands on Day 5 of pregnancy. Toluidine blue-stained section of Epon-embedded material. $\times 550$. (By courtesy of Dr S. Reinius.)

FIG. 3. Mouse uterine lumen on Day 5 of pregnancy. Cryostat section showing AANA-ase activity. $\times 470$.

Fis. 4. Mouse uterine lumen on Day 5 of pregnancy. Toluidine blue-stained section of Epon-embedded material. $\times 470$. (By courtesy of Dr S. Reinius.) 
PLATE 2
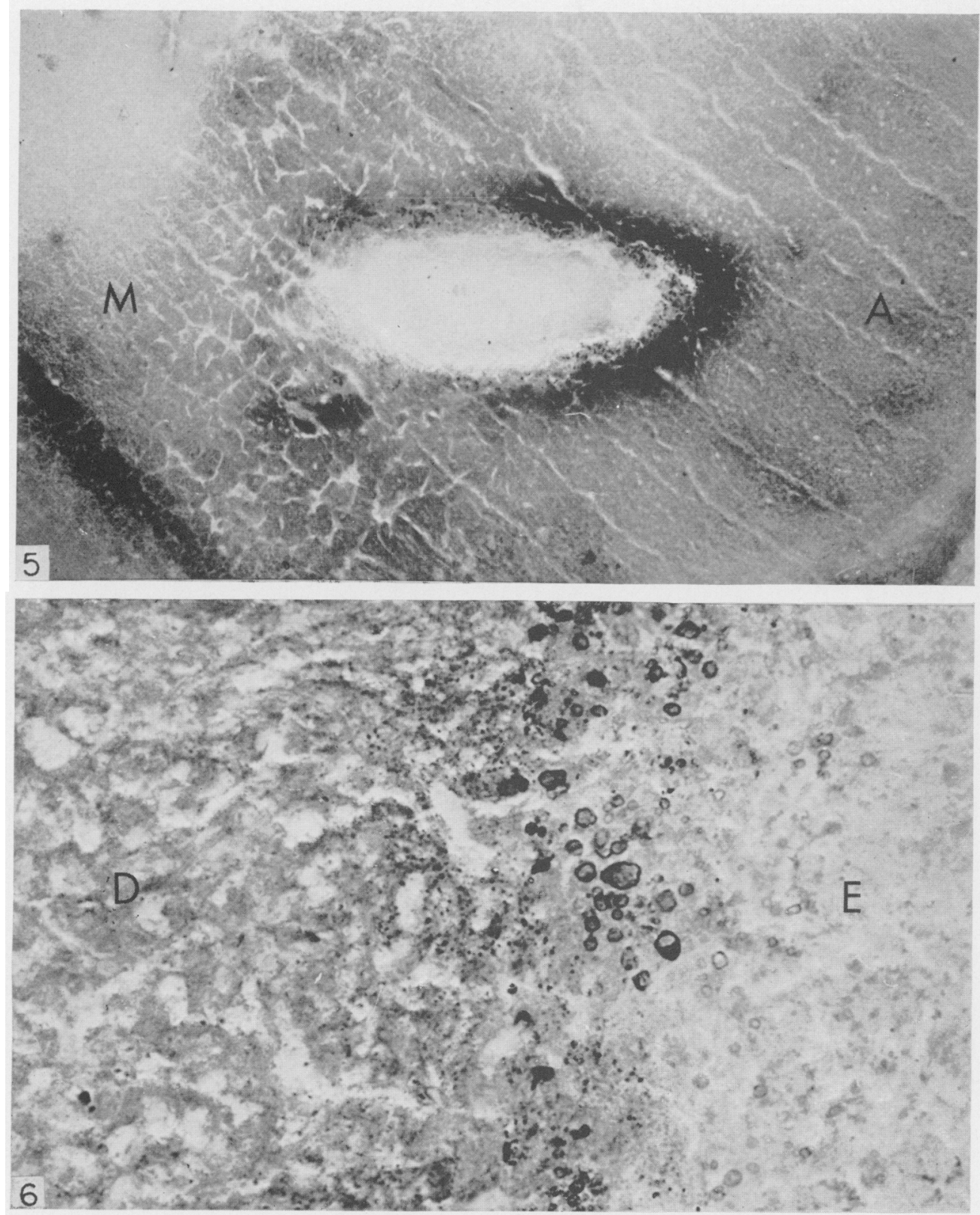

FIG. 5. Mouse implantation site on Day 8 of pregnancy. Ciryostat section showing AANAase activity. No preincubation. $M=$ mesometrial direction; $A=$ antinesometrial region. Note active region antimesometrial to the embryo. fading off in the mesometrial direction. The embryonic tissuc is inactive. $\times 40$.

FIc. 6. Region mid-way between mesometrial and antimesometrial end of the embryo (junction of embryonic and maternal tissues). $\mathrm{E}=$ embryonic trophoblast; $\mathrm{D}=$ maternal decidua. Note $A$ AN $A$-ase activity in vacuoles adjacent to invading trophoblast tissue $\times 800$. 
diffusely cytoplasmic and bright red. In unfixed tissues, the enzyme activities were always of the particulate type (glandular epithelium) or of the vacuolar type (luminal epithelium) and the stain was always bluish. Corresponding reaction intensities were obtained at an incubation time of 30 to $40 \mathrm{~min}$ for unfixed sections and about $3 \mathrm{hr}$ for fixed sections.

TABle 1

RELATIVE ACTIVITIES OF AANA-ASE IN GLANDULAR AND LUMINAL EPITHELIA OF THE MOUSE UTERUS IN DIFFERENT STAGES OF PREGNANGY AND DIFFERENT HORMONAL STATES

\begin{tabular}{|c|c|c|c|c|}
\hline $\begin{array}{l}\text { Type of } \\
\text { uterus }\end{array}$ & $\begin{array}{c}\text { No. of } \\
\text { animals }\end{array}$ & Preincubation & $\begin{array}{l}\text { Glandular } \\
\text { epithelium* }\end{array}$ & $\begin{array}{c}\text { Luminal } \\
\text { epithelium* }\end{array}$ \\
\hline Day $2 / 9 \dagger$ & 8 & $\begin{array}{l}\text { Cysteine+EDTA } \\
\mathrm{Mn}^{2+} \\
\text { None }\end{array}$ & $\begin{array}{l}\overline{+}+ \\
+(+)\end{array}$ & $\bar{t}$ \\
\hline Day 4/9 & 2 & $\begin{array}{l}\text { Cysteine+EDTA } \\
\text { Mn }^{2+} \\
\text { None }\end{array}$ & $\begin{array}{l}\bar{t}+(+) \\
++(+)\end{array}$ & $\vec{t}$ \\
\hline Day $5 / 9$ & 7 & $\begin{array}{l}\text { Cysteine + EDTA } \\
\mathrm{Mn}^{2+} \\
\text { None }\end{array}$ & $\begin{array}{l}\bar{t}+ \\
++(+)\end{array}$ & $\begin{array}{l}\overline{+}(+) \\
+(+)\end{array}$ \\
\hline Day $6 / 9$ & $3 \ddagger$ & $\begin{array}{l}\text { Cysteine + EDTA } \\
\mathrm{Mn}^{2+} \\
\text { None }\end{array}$ & $\begin{array}{l}\overline{+} \\
+(+)\end{array}$ & $\begin{array}{l}+ \\
+\end{array}$ \\
\hline Day $8 / 9$ & 6 & $\begin{array}{l}\text { Cysteine + EDTA } \\
\mathrm{Mn}^{2+} \\
\text { None }\end{array}$ & $\begin{array}{l}\bar{t}+ \\
+(+)\end{array}$ & $\begin{array}{l}- \\
(+) \\
(+)\end{array}$ \\
\hline Spayed & 8 & $\begin{array}{l}\text { Cysteine + EDTA } \\
\text { Mn }^{2+} \\
\text { None }\end{array}$ & $\begin{array}{l}\overline{(+)} \\
(+)\end{array}$ & $\begin{array}{l}\overrightarrow{(+)} \\
(+)\end{array}$ \\
\hline Spayed $+A$ & 3 & $\begin{array}{l}\text { Gysteine+EDTA } \\
\mathrm{Mn}^{2+} \\
\text { None }\end{array}$ & $\begin{array}{l}\overline{+} \\
+ \\
+\end{array}$ & $\begin{array}{l}- \\
(+)\end{array}$ \\
\hline Spayed +B & 5 & $\begin{array}{l}\text { Cysteine+EDTA } \\
\mathrm{Mn}^{2+} \\
\text { None }\end{array}$ & $\begin{array}{l}\bar{t}+t \\
+t(t)\end{array}$ & $\begin{array}{l}\bar{t} \\
+(+) \\
+(t)\end{array}$ \\
\hline Spayed $+C$ & 5 & $\begin{array}{l}\text { Cysteine + EDTA } \\
\mathrm{Mn}^{2+} \\
\text { None }\end{array}$ & $\begin{array}{l}\overline{+} \\
++ \\
++(+)\end{array}$ & $\begin{array}{l}\overline{+} \\
+(+) \\
+(+)\end{array}$ \\
\hline
\end{tabular}

$\mathrm{A}=1 \mathrm{mg}$ progesterone subcutaneously daily for 2 days; $B=1 \mathrm{mg}$ progesterone subcutaneously daily for 6 days; $\mathbf{C}=1 \mathrm{mg}$ progesterone subcutaneously daily for 6 days $+0 \cdot 1 \mu \mathrm{g}$ oestradiol-17 $\beta$ after 5 days progesterone treatment.

* The two kinds of epithelia should not be reciprocally compared (see text).

+ Day $2 / 9=$ Day 2 at 09.00 hours, etc.

$\ddagger$ One of these animals had very low glandular activity.

The glandular activity was high in relation to the activity of any other uterine structure but different degrees of glandular activity were observed in adjacent glands.

The implantation sites (Day 8) showed a diffuse activity, most pronounced antimesometrially to the embryo, the activity fading off in the mesometrial direction (Pl. 2, Fig. 5). The embryonic tissues proper, the endoderm and ectoderm, were inactive (Pl. 2, Fig. 6). On the mesometrial side of the deciduomal 
swelling, the glandular epithelium showed some activity, though this was less than that on Day 5.

\section{DISCUSSION}

The basis for the present histochemical reactions is the hydrolysis by tissue enzymes of aminoacid naphthylamides and the simultaneous coupling of the liberated naphthylamine with a tetrazonium salt to produce an azo-dye (Nachlas et al., 1957). The stability of this compound is rather low but can be increased by its chelation of copper.

A further development of this technique has indicated that a selective demonstration of cathepsin B (Keilová \& Keil, 1969) is possible under special conditions (Sylvén, 1968). Biochemical evidence has demonstrated that cathep$\sin \mathrm{B}$ cleaves certain aminoacid naphthylamides at an acid $\mathrm{pH}$, where aminopeptidases are virtually inactive (Sylvén \& Snellman, 1968). Interestingly, the histochemical application of this method showed cathepsin B to be localized in autolytic vacuoles and enlarged lysosomes, suggesting a relation to cell injury at an early stage (Niemi \& Sylvén, 1969).

The specificity of the present method has been a matter of controversy. Cysteine plus EDTA is claimed to stimulate cathepsin B but to inhibit aminopeptidases, while the reverse is the case for $\mathrm{Mn}^{2+}$ (Sylvén, 1968).

The present results demonstrate (cf. Table l) that, in the mouse uterus at $\mathrm{pH} 5 \cdot 5$, any LNA-splitting enzyme activity is abolished by preincubation in cysteine plus EDTA, while only a little stimulation is attained by $\mathrm{Mn}^{2+}$. This indicates the presence of LNA-splitting enzyme(-s) at $\mathrm{pH} 5.5$ other than cathep$\sin \mathrm{B}$, a finding which is contrary to the statement by Sylvén (1968) that the present histochemical procedure will exclude all LNA-splitting enzymatic activity but cathepsin $\mathrm{B}$ if carried out at $\mathrm{pH} 5 \cdot 5$. The uterine activity found is most correctly ascribed to aminoacylnaphthylamidase (-s) (AANA-ase) since LNA is split by a wide variety of enzymes irrespective of its L-leucyl component (Sylvén, 1968).

The possibility that the stain observed merely represents non-specific aggregates of substrate is contradicted firstly by the fact that no Diazo Blue B precipitate whatsoever was found in the first histochemical procedure, where all AANA-ase activity was inhibited, secondly by the different colours of Cuchelating azo-dye (bluish) and the tetrazonium salt (brownish) and thirdly by the distinct variation of azo-dye in animals of different hormonal states (cf. McCabe \& Chayen, 1965).

The particulate and vacuolar appearances of the AANA-ase localizations seem to be a constant feature of glandular and luminal epithelium respectively. In Epon-embedded sections, lipid inclusions of the luminal epithelium correspond very closely to the vacuoles in the cryostat sections (Pl. 1, Figs. 3 and 4) while-at the light microscope level-no clear corresponding structure could be demonstrated concerning the glands (Pl. 1, Figs. 1 and 2). There are some lipid inclusions also in the glandular epithelium but, obviously, these cannot account for the activity in the glands (cf. Pl. 1, Figs. 1 and 3). The apparent localization of AANA-ase in the walls of these luminal vacuoles is in accordance 
with the general statement by Felgenhauer \& Glenner (1966) that peptidases in general are membrane-bound.

In the spayed and hormone-treated mice, the AANA-ase pattern that approaches the glandular appearance on Day 5 most closely is the one found in mice treated for 6 days with progesterone. The addition of oestradiol on the 5 th day of progesterone treatment did not augment the intensity any further. Lammes (1963) reported a peak intensity on Day 6 of pseudopregnancy in mice in comparison with Days 3 and 9, using LNA and Garnet GBC in the substrate solution. He noted a strong apical reaction in the glandular epithelium at this time. A similar localization could not be demonstrated in the present work. Different histochemical methods may account for this discrepancy.

In a biochemical study of the uterus of the pseudopregnant rat, Rich (1965) found a maximum on Day 6 of an acid proteolytic enzyme using denatured haemoglobin as substrate. Only the organ as a whole was examined. Similar results have been reached by Wood \& Psychoyos (1967) in the pseudopregnant rat. Their findings are in agreement with those of Rich and are analogous to the present histochemical results in the mouse.

The functional significance of the observed AANA-ase activity in the mouse uterus is unclear. Generally, the two effects ascribed to these types of enzymes concern protein breakdown or synthesis (Burstone, 1962). Of these, at least the former process can be expected to occur in the mouse uterus during implantation: firstly, in connection with the disappearance of the zona pellucida, where a uterine zona 'lysin' has been postulated and secondly, in connection with the disappearance of the progestational uterine secretion as the epithelial attachment reaction occurs.

The disappearance of the zona pellucida is thought to be in some way related to a 'lysin' which is evidently oestrogen-dependent and possibly of uterine origin (McLaren, 1970). The time of maximum AANA-ase activity and that of zona loss seem to coincide in normal pregnancy. Some animals examined on Day 4 and on Day 6 were found to have irregularly the pattern of Day- 5 animals. However, the appearance of the Day-5 AANA-ase pattern after 6 days of treatment with progesterone alone, during which shedding delay is to occur, makes AANA-ase an unlikely 'zona lysin'.

The uterine secretion of early pregnancy disappears before the attachment reaction in the mouse on Day 5. A similar picture regarding the attachment reaction can be achieved by progesterone alone (Martin, Finn \& Carter, 1970). Thus, there seems to be a parallelism between maximum AANA-ase activity and disappearance of the uterine secretion in the mouse. This finding suggests a rôle for AANA-ase in the absorption process of uterine secretion which is believed to occur before the attachment reaction.

The present findings do not lend any specific support to the hypothesis of an autolytic capacity in the luminal epithelium. No cathepsin B activity could be demonstrated at places with established proteolytic activity. However, the luminal epithelium might show this capacity in other states where catabolism is believed to occur (Thiery \& Willighagen, 1963).

The implantation sites are active mainly in the antimesometrial region, which, unlike the mesometrial region, is known in rodents to be a lipid-rich 
zone (Krehbiel, 1937). The vacuolar AANA-ase activity found here is similar to that found in the lipid inclusions of the luminal epithelium but the vacuoles are of greater variety. This periembryonic activity is similar to that described in the area of invading tumours (Glenner, Burstone \& Meyer, 1959; Hess, $1960 \mathrm{a}, \mathrm{b})$. Thus, the invading trophoblast tissue appears to elicit the breakdown of the host tissue in the same way as an invasive tumour and there seems to be an enzymatic analogy between invading trophoblastic tissue and tumour growth. This periembryonic AANA-ase activity corresponds closely to the proteolytic activity earlier demonstrated by means of the gelatin digestion method (Bergström, 1970).

The conclusion of the present findings is that there are two different epithelial AANA-ase reactions in the mouse uterus, a particulate reaction in the glandular epithelium and a vacuolar one in the luminal epithelium, both of which seem to be in some way related to the implantation process, possibly to the breakdown of a secretory product.

\section{ACKNOWLEDGMENTS}

The author is indebted to Professor Ove Nilsson for valuable advice and criticism. Mr Alf Johansson and Miss Kerstin Rystedt provided skilled technical assistance, which is gratefully acknowledged. The hormone preparations were kindly provided by Leo $\mathrm{AB}$, Helsingborg, Sweden. This investigation was supported by a grant from the Swedish Medical Research Council, Project No. B71-12X-70.

\section{REFERENCES}

Bergström, S. (1970) Estimation of proteolytic activity at mouse implantation sites by the gelatin digestion method. F. Reprod. Fert. 23, 481.

Burstone, M. S. (1962) Enzyme histochemistry and its application in the study of neoplasms. Academic Press, New York.

Felgenhauer, K. \& Glenner, G. G. (1966) The enzymatic hydrolysis of amino-acid $\beta$-naphthylamides. II. Partial purification and properties of a particle bound cobalt-activated rat kidney aminopeptidase. F. Histochem. Cytochem. 14, 401.

Glenner, G. G., Burstone, M. S. \& MeYer, D. B. (1959) A study of aminopeptidase activity in the stroma of neoplastic tissue, with a comparison of histochemical techniques. F. natl Cancer Inst. 23, 857.

Hess, R. (1960a) Histochemisch erfassbare proteolytische Aktivität im Stroma von Tumortransplantaten. Oncologia, Basel, 13, 110.

Hess, R. (1960b) Localization of a cathepsin-like and aminopeptidase activity in various solid tumor transplants. Cancer Res. 20, 940.

KeILOVÁ, H. \& KeIL, B. (1969) Isolation and specificity of cathepsin B. FEBS Letters, 4, 295.

KREHBIEL, R. H. (1937) Cytological studies of the decidual reaction in the rat during early pregnancy and in the production of deciduomata. Physiol. Zoöl. 10, 212.

Lammes, F. B. (1963) Het endometrium van de muis. Thesis, Leiden.

MCCABE, M. \& ChaYen, J. (1965) The demonstration of latent particulate aminopeptidase activity. Fl R. microsc. Soc. 84, 361.

McLaren, A. (1970) The fate of the zona pellucida in mice. F. Embryol. exp. Morph. 23, 1.

Martin, L., FinN, G. A. \& CARTER, J. (1970) Effects of progesterone and oestradiol-17 $\beta$ on the luminal epithelium of the mouse uterus. F. Reprod. Fert. 21, 461.

Nachlas, M. M., Crawford, D. T. \& Seligman, A. M. (1957) The histochemical demonstration of leucine aminopeptidase. 7. Histochem. Cytochem. 5, 264.

NIEMI, M. \& SyLvÉn, B. (1969) The naphthylamidase reaction as a diagnostic tool for the demonstration of cellular injury and autophagy. Histochemie, 18, 40. 
Rich, R. A. (1965) Uterine, ovarian and adrenal proteases in the normally cycling and pseudopregnant rat. Thesis, Logan.

Sandström, B. \& Westman, J. (1969) Non-freezing light- and electron-microscopic enzyme histochemistry by means of polyethylene glycol embedding. Histochemie, 19, 181 .

Sylvén, B. (1968) Studies on the histochemical 'leucine aminopeptidase' reaction. VI. The selective demonstration of cathepsin B activity by means of the naphthylamide reaction. Histochemie, 15, 150.

Sylven, B. \& Snellman, O. (1968) Studies on the histochemical 'leucine aminopeptidase' reaction. V. Cathepsin B as a potential effector of LNA hydrolysis. Histochemie, 12, 240.

ThizRy, M. \& Willighagen, R. G. J. (1963) An enzymatic-histochemical study of the corpus uteri of the mouse. Anat. Rec. 146, 263.

Wood, C. \& Psychoyos, A. (1967) Activité de certaines enzymes hydrolytiques dans l'endomètre et le myomètre au cours de la pseudogestation et de divers états de réceptivité utérine chez la ratte. C. r. hebd. Séanc. Acad. Sci., Paris, 265, 141. 